\title{
Reliability and Validity of Infant-Toddler Auditory and Communicative Behavioral Checklist
}

\author{
Jinsook Kim¹, Kyeongyeon Park² \\ 'Division of Speech Pathology and Audiology, Research Institute of Audiology and Speech Pathology, College of Natural Science, Hallym University, \\ Chuncheon, Korea \\ 2Department of Speech Pathology and Audiology, Graduate School, Hallym University, Chuncheon, Korea
}

영유아 청각 및 의사소통 행동 체크리스트의 신뢰도와 타당도 검증

김 진 숙 $\cdot$ 박 경 연 $^{2}$

한림대학교 자연과학대학 언어청각학부 · 청각언어연구소 ${ }^{1}$, 한림대학교 일반대학원 언어병리청각학과 ${ }^{2}$

\begin{abstract}
Purpose: The objective of this study was to analyze the reliability and validity, and compare the Infant-Toddler Auditory and Communicative Behavioral Checklist (IT-ACBC) to general developmental levels of Korean Developmental Screening Test for infant \& children (K-DST) for identifying characteristics of the checklist. Methods: IT-ACBC were administered by 287 parents of the normally developing infants aged from 1-26 months. After considering internal consistency reliability, frequency of response to each month group, and questions from respondents, 36 items, 3 items for 12 month groups, were finally extracted from the preliminary items. The internal consistency of items and test-retest reliability were calculated. The validity for items were conducted by attempting a concurrent validity analysis. Average and standard deviation of IT-ACBC was analyzed to standardize a criterion. The correlation between auditory and communicative behavioral ability of IT-ACBC and 6 general developmental skills of K-DST scores were obtained to identify their relationship. Results: The Cronbach's alpha coefficient of IT-ACBC was 0.964 . The test-retest reliability was quite high with $r=0.962$. The score of the checklist was significantly correlated with 'LittIEARS Auditory Questionnaire-Korean' score. The score of the IT-ACBC was significantly correlated with the language score of K-DST $(r=0.426)$. Conclusion: IT-ACBC was developed and standardized scores were provided to evaluate auditory and communicative behavior in typically developing infants and toddlers. IT-ACBC can be utilized for checking auditory and communicative behaviors briefly. Further, IT-ACBC also can be utilized to assess auditory and communicative behaviors for multi-handicapped children comparing with other functions of K-DST.
\end{abstract}

Key Words: Infant-toddler, Development of auditory and communicative behavior, Infant development, Checklist, Screening test.

Received: January 12, 2017 / Revised: March 13, 2017 / Accepted: April 7, 2017

Correspondence: Jinsook Kim, Division of Speech Pathology and Audiology, Research Institute of Audiology and Speech Pathology, College of Natural Science, Hallym University, 1 Hallimdaehak-gil, Chuncheon 24252, Korea

Tel: +82-33-248-2213 / Fax: +82-33-256-3420 / E-mail: jskim@hallym.ac.kr

\section{INTRODUCTION}

영유아기의 발달 중에서 청각의 발달은 태아기부터 구조와 기능이 형성되기 시작하여 의사소통 발달과 그 외 발달에 영향 을 미친다(Tait et al., 2007). 태아는 임신 8주에 청각기관이 구 조적으로 형성되기 시작하여 임신 20주경부터 해부학적으로 초 기 듣기 기능을 할 수 있도록 발달한다(Hall, 2000; Pujol \& Lavigne-Rebillard, 1992). 태아는 자궁에서 골도로 듣게 되며,
양수의 진동을 통해 소리가 전달되어 $1,000 \mathrm{~Hz}$ 이상의 소리는 20 30 dB 감쇄하여 듣게 되는데(Lecanuet et al., 1998), 이렇 게 태아기부터 들은 소리는 호흡의 변화, 심장 박동 수 변화, 안 구운동, 손가락을 빨거나 입을 우물거리는 행동 등으로 반응하 게 되는 것을 관찰할 수 있다(Abrams \& Gerhardt, 2000). 따 라서 영유아 초기의 듣기 발달은 태내에서부터 형성되며 다양 한 행동으로 반응할 수 있는 중요하고도 독특한 능력이라 할 수 있다. 
선천성 청각장애를 가지고 태어나는 신생아는 1,000 명당 0.9 명에서 5.9명이다(Korean Otological Society \& The Korean Audiological Society, 2011). 이는 갑상선기능저하증, 페닐케토 산뇨증, 낭성섬유증 등의 질환보다 출현율이 높아 신생아 청각 선별검사에 대한 관심이 증가하고 있다(Kim, 2007). 또한, 중복 장애 영유아 중 귀의 구조적 기형이나 다른 중이 질환을 가지 고 있는 아동은 다른 영역에서도 경도의 지연을 보인다(Shoup $\&$ Roeser, 2007). 그러므로 모든 발달장애를 가지고 있거나 발 달이 지연된 영유아들의 주파수 특이 정보가 얻어질 때까지 청 각학적 평가가 이루어져야 한다. 청력손실이 확인되지 않고 중 복장애가 진행되지 않는다면 더 이상 추적검사가 필요하지 않지 만, 그 장애가 거대세포바이러스, 중추 신경계 기능 장애와 같이 진행성일 가능성이 있거나, 진행성 난청을 가진 다운증후군과 같이 변동성일 경우 정기적인 청각학적 평가가 필요하다. 초기 인공와우 수술에서 중복장애가 있는 청각장애 영유아의 인공와 우 수술은 제한적이었지만 경험과 기술의 발달, 긍정적 결과로 기준이 확대되었으며, 현재 이러한 영유아들의 인공와우 착용 수도 증가하였다(Hans et al., 2010; Meinzen-Derr et al., 2010). 중복장애를 가진 청각장애 영유아의 인공와우 수술기준이 확대 됨에 따라 중복장애 영유아의 발달 수준에 적절한 청력검사를 시행하기 위해서는 듣기뿐 아니라 전반적인 영역에 대한 평가가 필요하게 되었다. 국내외 영유아의 듣기발달 검사도구와 전반적 영역의 발달 검사도구를 살펴보면 다음과 같다.

먼저 대표적인 국내외 듣기 발달 평가도구로는 미국의 NIDCD 포털사이트(https://www.nidcd.nih.gov/health/yourbabys-hearing-and-communicative-development-checklist) 에서 확인할 수 있는 'Your Baby's Hearing And Communicative Development Checklist'와 캐나다의 The Hearing Foundation of Canada 포털사이트(http://www.hearingfoundation. ca/babys-communication-checklist/)에서 확인할 수 있는 'Baby's Communication Checklist'가 있다. 이 평가도구들의 경우 영유아의 청각 및 의사소통 행동을 부모가 쉽게 작성할 수 있지만, 문항 수와 월령구간이 일정치 않아 초기 영유아의 정기적인 듣기평가와 조기 재활에 활용하기에 적절치 않은 것 으로 분석되었다(NIDCID, 2010; The Hearing Foundation of Canada, 2016). 더욱이 이러한 점은 영유아 초기의 발달이 매 우 빠른 속도로 진행된다는 점을 고려할 때 월령구간을 세분화 하여 행동특성을 점검할 필요가 있다(Yee \& Oh, 2006)는 연 구자들의 의견이 반영되지 않은 도구로 평가할 수 있다. 더 나아 가 문화·정서적, 언어, 발달 단계의 차이로 그대로 번역하여 사 용하는 데 무리가 있다. 국내의 도구 중 '한국어판 영유아 언어 및 의사소통 선별검사'(Pae et al., 2015)는 4 36개월 영유아의 언어능력을 평가하는 데 사용 가능하나 청각영역을 포함하지
않았고, '영유아 발달 선별검사를 위한 체크리스트'(Ju et al., 2009), '한국 영유아 발달선별검사'(Eun, 2012; Eun \& Jeong, 2013)도 전반적 영역 중 언어영역에서 언어발달 중심의 문항들 로 구성되어 영유아 초기의 청각 및 의사소통 행동을 평가하는 데 한계가 있다. 또 다른 연구인 '영유아청각행동발달검사'(Lee \& Jang, 2010)에서 제시한 문항들은 생후 48개월까지 월령구간 을 5 개월 간격으로 구성하여 초기의 듣기 발달을 평가하는 데 부족함이 있고, 영유아의 듣기 평가도구인 영유아 듣기 발달 평 가를 위한 질문지(LittlEARS Auditory Questionnaire Korean, LEAQ-K)는 Coninx et al.(2003)이 개발한 영문 버전을 한국 영유아에게 사용할 수 있도록 번역하여 한국의 문화·정서적 측 면이 반영되지 못한 한계가 있다. LEAQ-K는 청력이 정상인 경 우 생후 24개월까지, 청각장애인 경우 보장구 착용 후 2년까지 평가하므로 어린 영유아의 듣기 발달을 평가할 수 있다(Sohn et al., 2015). 그러나 총 35문항은 듣기발달의 순차적인 과정을 반 영하여 배열되었고, 월령구간을 구분할 수 없어 특정 시기의 청 각 및 의사소통 행동을 평가하는 선별검사도구로 사용하기에 는 무리가 있다. 따라서 국내에 신뢰도와 타당도가 검증되고 한국의 문화와 정서를 반영하고 간편하게 사용할 수 있는 표준 화된 영유아의 청각 및 의사소통 행동 평가도구가 필요하다.

국내에는 영유아의 전반적 발달평가를 위한 평가도구로 한국 영유아 발달선별검사(Korean Developmental Screening Test for Infants and Children, K-DST)가 있다. 이는 영유아 건강검 진 사업의 일환으로 보건복지부와 질병관리본부의 지원으로 대 한소아과학회 및 관련 분야 전문가들이 함께 개발한 한국의 실 정에 맞는 영유아 선별검사도구이다(Eun, 2012; Eun \& Jeong, 2013). 검사 대상은 취학 전 연령인 6세 미만 영유아(4 71개월) 이며, 다양한 영역에서 습득하는 발달 기술을 종합적으로 평가 하기 위하여 부모가 짧은 시간에 쉽게 아기의 행동을 통해 응 답할 수 있는 부모보고형 설문지이며 웹상에서도 사용 가능하 다. 생후 초기 월령 집단인 경우 발달 속도가 매우 빠르므로 월 령구간의 간격은 23 개월까지 2 개월, 35 개월까지 3 개월, 71 개월 까지 6개월로 구성하였다. 검사 문항은 영유아의 발달을 총 6 개 영역(대근육 운동, 소근육 운동, 인지, 언어, 사회성, 자조)으로 나누었으며 영역별로 8문항이 있다. K-DST는 국민건강보험공 단에서 실시하고 있는 영유아 건강검진프로그램의 검진 중 발 달 평가를 위해 사용되고 있으며, 특히 K-DST의 경우 어린이 집이나 유치원에 건강검진결과통보서를 제출해야 입소 및 재원 이 되므로 모든 영유아가 검진에 참여하고 있다. 또 다른 영유 아의 전반적인 발달검사도구로 $\mathrm{K}-\mathrm{DST}$ 와 마찬가지로 6개 영역 을 검사하는 영아선별·교육진단검사(Developmental assessment for the Early intervention Program planning)가 있으나 월령구간이 일정치 않아 K-DST보다 비활용적인 것으로 생각된 
다(Chang et al., 2011).

언어발달지체 영유아 집단의 언어 및 의사소통 행동과 인지, 운동기능, 사회성 발달 영역 간 비교에서 유의미한 차이를 보인 선행연구에서도 나타났듯이(Lee, 2011), 의사소통 관련 장애는 전반적 영역의 평가가 더욱 필요하다. 더욱이 청각 이외의 다른 영역의 발달 지연이 청력손실과 관련이 있는 점을 고려할 때 듣기 와 전반적 발달을 함께 평가하는 것은 매우 중요하다. 그러나 이 러한 청각장애나 그 외 중복장애 아동에 대하여 영유아시기부 터 청각행동의 발달을 선별할 수 있는 도구가 국내에 없기 때문 에 정기적인 청각학적 평가가 제대로 이루어지지 못하고 있다.

여러 발달 영역에 기반이 되는 청각 및 의사소통 행동을 독립 적이고 체계적인 발달단계에 기반을 두어 평가하기 위하여 영 유아 청각 및 의사소통 행동 체크리스트(Infant-Toddler Auditory and Communicative Behavioral Checklist, IT-ACBC)가 최근 개발되었다(Park \& Kim, 2016). 총 7단계의 과정을 거쳐 개발되었는데, 1 단계에서는 국내외 청각 및 의사소통 행동 발 달과 관련된 15 개 검사도구의 문항들을 분석하여 청각 및 의 사소통 행동 문항으로 적절한 465 개의 문항을 정리하고, 2단계 에서는 국내 영유아의 전반적인 발달 영역과 청각 및 의사소통 행동 발달과정을 비교하기 위하여 월령구간을 우리나라 국가 건강검진에 사용되고 있는 $\mathrm{K}-\mathrm{DST}$ 를 참조하여 일치시켰다. 3 단 계에서는 465개의 총 문항을 청각 및 의사소통 행동 위계와 선 행연구 분석을 통해 큰 소리에 반응, 익숙한 목소리에 반응, 옹 알이, 요구하기 등 33개의 키워드로 분류하고, 4단계에서는 12 개의 월령구간별로 6 문항씩 예비 72 문항을 구성하였다. 이를 5 단계에서 선천적 장애나 청각 및 언어장애가 없다고 보고한 1 26개월 영유아의 주 양육자 114명을 대상으로 응답을 얻어 6단계에서 월령구간별 신뢰도, 해당 월령구간 외 문항에서 응 답이 자주 나타난 경우, 기타 질문 수 등을 고려하여 최종 36문 항을 선정하였다. 7단계에서는 내적 일치도 계수를 Cronbach's $\alpha$ 를 통해 산출하였는데, 월령구간별 내적일치도가 모두 0.700 이상이었다. 하지만, 저자들은 중복장애를 가진 청각장애 영유 아의 청각 및 의사소통 행동을 함께 평가하기 위한 검사도구 개발을 위해 우선으로 개발된 IT-ACBC가 신뢰도와 타당도가 검증된 검사지인지 추가 대상자를 모집할 필요가 있다고 기록 하고 있다. 또한, 성별 간 차이를 분석하지 못한 한계가 있어 차 후 연구에서 자료수집량을 늘려 성별 간 차이가 있는지도 확인 하기를 독려하였다. 더 나아가 IT-ACBC가 건청 영유아를 판 별할 수 있는 도구로 표준화되어 활용될 수 있도록 월령구간별 평균, 표준편차, 절단점 등이 필요하다고 보고하였다.

따라서 본 연구는 태아기의 완성과 영유아 초기의 듣기 능력 을 정확하게 평가하여 영유아의 의사소통 능력을 분석하고 전 반적 영역과 비교할 수 있도록 개발된 IT-ACBC를 더 많은 대
상자를 통해 내적신뢰도, 검사-재검사신뢰도, 공인타당도 등을 검증하고, 이를 전반적인 발달평가도구와 비교하여 평가도구의 특성을 확인하고자 하였다. 세 가지 연구 목표는 다음과 같다. 첫째, 영유아의 초기 청각 및 의사소통 행동을 평가하기 위하 여 개발된 IT-ACBC의 신뢰도와 타당도를 검증하였다. 둘째, $\mathrm{IT}-\mathrm{ACBC}$ 를 표준화할 수 있도록 월령구간별 평균, 표준편차, 절단점 분석을 통해 영유아의 초기 청능재활에 기초선을 평가 하고 재활 후 진전도 평가를 위한 간단한 평가방법과 기준을 제시하였다. 셋째, 전반적 영역의 성장과 발달을 평가하는 $\mathrm{K}-$ $\mathrm{DST}$ 검사 도구와 상관성을 평가하여 K-DST의 영역별 평가가 $\mathrm{IT}-\mathrm{ACBC}$ 와 어떠한 상관이 있는지 확인하고 IT-ACBC 검사가 영유아의 전반적인 발달 영역 내에서 나타낼 수 있는 특성을 분석하였다.

\section{MATERIALS AND METHODS}

\section{연구 대상}

선천적 장애나 청각 및 언어 장애가 없다고 보고한 1 26개 월 정상 영유아의 주 양육자를 대상으로 하였다. 월령구간별로 $1 \sim 3$ 개월은 24명, 4 5개월은 25명, 6 7개월은 24명, 8 9개월은 23명, 10 11개월은 21명, 12 13개월은 24명, 14 15개월은 21명, 16 17개월은 28명, 18 19개월은 21명, 20 21개월은 25명, 22 23개월은 25명, 24 26개월은 26명으로, 총 287명의 주 양 육자가 참여하였다. 287 명의 참여자 중 청각 및 의사소통 행동 을 6개의 전반적 영역과 비교하기 위하여 IT-ACBC와 함께 $\mathrm{K}-\mathrm{DST}$ 에 응답한 경우는 4 5개월은 11명, 6 7개월은 14 명, 8 9개월은 16명, 10 11개월은 12명, 12 13개월은 13명, 14 15 개월은 12 명, 16 17개월은 22명, 18 19개월은 16 명, 20 21개월 은 15명, 22 23개월은 15명, 24 26개월은 18명으로, 총 164명이 었다. 검사-재검사 평가는 1 3개월은 3명, 6 7개월은 5명, 8 9 개월은 9명, 10 11개월은 2명, 12 13개월은 8명, 14 15개월은 3명, 16 17개월은 11명, 18 19개월은 9명, 20 21개월은 6명, 22 23개 월은 6명, 24 26개월은 8명으로, 총 70명의 주 양육자가 참여하 였다. 본 연구는 한림대학교 생명윤리위원회의 승인을 받아 진 행되었다(IRB 번호: HIRB-2016-051).

\section{연구 방법}

평가는 1차와 2차로 나누어 진행되었다. 1차 평가에서는 IT$\mathrm{ACBC}$ 와 $\mathrm{K}-\mathrm{DST}$ 검사도구의 응답을 받았고, 1 2주 후 2차 평 가에서는 공인타당도와 검사-재검사 신뢰도를 위하여 IT$\mathrm{ACBC}$ 와 LEAQ-K의 응답을 받았다(Sohn et al., 2015). 재검 사 기간은 영유아의 빠른 발달을 고려하고 동일한 월령구간 내 평가를 실시하기 위하여 첫 검사 후 1 2주로 제한하였다. 
1 차 평가에서 IT-ACBC는 예비문항을 포함하여 총 72문항 의 응답을 수집하였으며, 응답 형식을 영유아가 과거나 현재에 보였던 청각 및 의사소통 행동은 '예'로 응답을 하고, 영유아에 게 아직 나타나지 않은 행동은 '아니오'로 응답하도록 하였다. 이외 기타 행동에 대해서는 기타란에 작성하도록 하였다. 각 문 항에서 '예' 응답은 1점, '아니오' 응답은 0점으로 계산하였다. 또 한, 각 문항에서 다른 청각 및 의사소통 행동을 조사하기 위하 여 기타란을 포함하여 본 시안에서 포함하지 못한 청각 및 의 사소통 행동이 있는지 확인하였다. 1 차 검사의 두 번째 검사도 구인 K-DST는 한국 영유아 발달선별검사 지침서에 따라 6개 의 영역의 각 질문 항목에 대하여 '잘 할 수 있다', '할 수 있는 편이다, '하지 못하는 편이다, '전혀 할 수 없다'의 네 가지 중 하 나를 선택하여 표기하도록 하였고, 각각 3점, 2점, 1점, 0 점을 부 여하였다. 영역별 총점을 계산하여 각 영역별로 제시된 절단점 에 근거하여 심화평가 권고, 추적검사 요망, 또래수준, 빠른 수 준으로 평가하였다(Eun \& Jeong, 2014). 2차 평가의 첫 번째 도 구인 IT-ACBC는 동일한 방법으로 응답을 얻어 평가되었다. 두 번째 검사도구인 $\mathrm{LEAQ}-\mathrm{K}$ 는 해당 검사의 원칙에 따라 35 개의 질문 항목에 대해 아동이 한 번이라도 확실하게 행동하였다면 '예', 한 번도 관찰되지 않았거나 확신할 수 없으면 '아니오'로 표 기하도록 하였으며, '예’ 응답에 1점을 부여하여 총점을 계산하 였다. LEAQ-K는 청력이 정상인 경우 1 24개월까지, 청각장애 인 경우 인공와우나 보청기를 착용하고 난 이후 2 년까지의 듣 기 발달을 평가하도록 구성되어, IT-ACBC와 비교할 때 월령구 간별로 구성된 문항은 아니지만, 평가 대상이 유사하며 청각 및 의사소통 행동 내용 중 듣기 발달을 평가하는 도구이므로, 공인타당성을 입증하는 평가도구로 선정하였다. 자료는 온라인 과 오프라인을 통해 수집하였다. 온라인은 'Google Docs'를 이 용해 웹 베이스로 설문형태를 제시하여 스마트폰이나 컴퓨터 로 응답할 수 있도록 하였다. 육아 카페 홍보를 통해 약 2달간 (2016년 9 10월) 자료를 수집하였고, NAVER 카페에서 육아/ 여성 주제의 대표 카페 중 연구 홍보성 글 게시가 가능한 카페 로 선정하였다. 오프라인은 춘천시에서 운영하는 꿈자람어린이 공원에 방문하여 직접 응답을 받았다. 온라인을 통해 응답한 경우 'Google Docs'를 통해 검사 응답시간을 확인 후 1주 후 2 차 검사 요청을 하였으며, 2 차 검사 응답시간을 확인하여 1 2주 간격으로 재검사가 이루어졌는지 확인하였다.

\section{통계 분석}

6 문항씩 12 구간으로 구성된 총 72 개의 예비문항으로부터 3 문항씩 12 구간으로 구성된 최종문항을 추출하기 위해, 예비문 항을 포함한 총 72 개의 IT-ACBC 문항에 대한 응답을 12 개의 월령구간별 6문항의 Cronbach's $\alpha$ 값을 각각 확인하여 항목 삭
제 시 6개 문항의 Cronbach's $\alpha$ 값이 증가하는 문항, 이해하기 어려워서 '예', '아니오' 척도로 응답하기 어려운 문항, 해당 월령 구간 외 구간에서 응답이 자주 나타난 문항 등을 분석하였다. 최종 IT-ACBC의 월령구간 간 발달 위계를 알아보기 위해 12 월 령 구간의 총 점수에 대한 일원분산분석을 실시하였다. LEAQ$\mathrm{K}$ 를 73명을 대상으로 수집하고 Pearson 상관분석을 실시하여 공인타당도를 점검하였다(Sohn et al., 2015). 검사 시행의 일관 성을 확인하기 위해 상관분석을 통하여 70명을 대상으로 첫 검 사 후 1 2주 검사-재검사 신뢰도를 측정하였다. IT-ACBC 역시 287명을 대상으로 얻어진 평균과 표준편차 결과로 절단점을 제 시하였고, 4 개의 척도로 구분하여 이를 K-DST와 상관분석을 실시하였다. 통계분석은 SPSS (Ver. 23.0, IBM Inc, Armonk, NY, USA)를 사용하였다.

\section{RESULTS}

\section{IT-ACBC 최종문항 추출과 신뢰도와 타당도 검증}

월령구간별 6 문항씩 12 구간으로 구성된 예비문항에서 월령 구간별 6 문항에 대하여 각각 신뢰도분석을 하여 전체 6 문항의 Cronbach's $\alpha$ 가 증가하는 문항을 일차적으로 제거하였다. 문 항 이외의 행동에 대해서 기타 항목에 응답한 수는 총 150 개 로, 전체 72 문항당 평균 1.91 개로 매우 적게 나타났다. 이 중 기 타 행동이나 질문이 가장 많았던 문항은 4 6개월 구간의 '소리 가 나는 장난감을 좋아한다였으며 총 질문 수는 11 개였다. 이 에 대한 기타 행동으로 '소리가 나지 않는 모든 장난감을 좋아 한다'가 있었고, '아직 장난감을 가지고 놀지 않는다'는 질문이 대다수였다. 또한, '오래 쳐다보거나 관심을 가지지만 좋아하는 지 모르겠다', '다른 장난감보다 오래 가지고 논다'는 질문이 있 었는데, 이는 어린 영유아가 소리 나는 장난감을 가지고 놀지 않거나 부모가 4 6개월의 영유아의 반응을 보고 좋아하는지 에 따라 '예' 또는 '아니오' 척도로 확인하는 데 어려움이 있는 것 으로 판단되어 문항에서 제거하였다. 마지막으로, 영유아의 해 당 월령구간별 6 문항의 '예’ 응답 빈도 수를 확인하여 구간 내 다른 문항에 비해 빈도 수 차이가 큰 문항을 순서대로 제거하 여 월령구간별 3 문항씩 12 구간의 총 36 문항을 구조적으로 완 성하였다.

IT-ACBC의 총 36문항의 Cronbach's $\alpha$ 값은 0.964이고, 월령 구간별 내적일치도가 가장 낮은 신뢰도를 보인 두 개 월령구간 인 1 3개월, 4 5개월은 각각 0.457 과 0.623 였고, 이들 월령구간 을 제외한 월령구간에서 모두 0.700 이상으로 높은 신뢰도를 보였다(Table 1).

IT-ACBC의 월령구간 간 발달위계를 알아보기 위해 12 월령 구간의 총 점수에 대한 일원분산분석을 실시한 결과, 월령구간 
이 높아짐에 따라 총 점수가 향상하였으며, 유의수준 $p<0.000$ 으로 유의미한 차이가 나타났다(Figure 1).

공인타당도를 검증하기 위해 73 명을 대상으로 $\mathrm{LEAQ}-\mathrm{K}$ 를 검사한 결과와 상관분석을 시행하여, $\mathrm{r}=0.906$ 으로 $p<0.001$

Table 1. Internal consistency reliability in value of Cronbach's $\alpha$ for each of 12 month groups

\begin{tabular}{cc}
\hline Age (months) & Cronbach's $\alpha$ \\
\hline $1-3$ & 0.457 \\
$4-5$ & 0.623 \\
$6-7$ & 0.773 \\
$8-9$ & 0.858 \\
$10-11$ & 0.870 \\
$12-13$ & 0.908 \\
$14-15$ & 0.917 \\
$16-17$ & 0.859 \\
$18-19$ & 0.872 \\
$20-21$ & 0.871 \\
$22-23$ & 0.831 \\
$24-26$ & 0.847 \\
Total & 0.964 \\
\hline
\end{tabular}

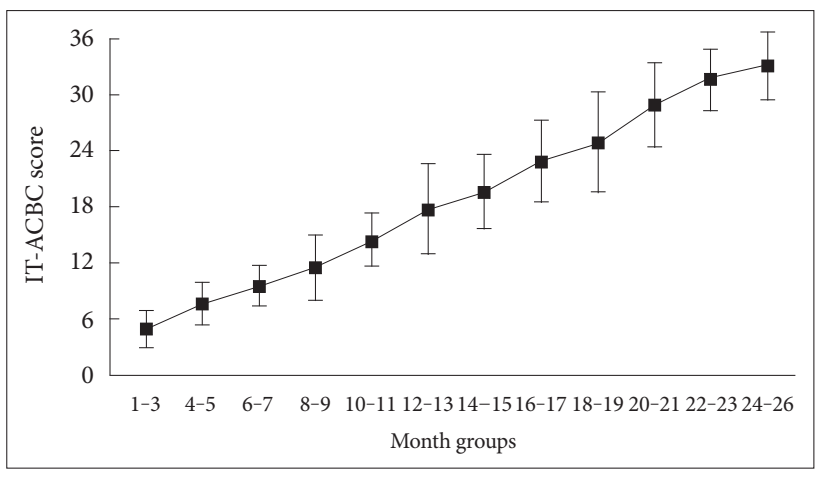

Figure 1. The scores of IT-ACBC for each of 12 month groups. ITACBC: Infant-Toddler Auditory and Communicative Behavioral Checklist.
유의수준에서 높은 상관관계를 확인하였다. 유사한 평가도구인 $\mathrm{LEAQ}-\mathrm{K}$ 와 높은 상관성은 IT-ACBC가 영유아의 청각 및 의사 소통 행동을 평가하기에 타당한 도구임을 입증하였다. 70명을 대 상으로 검사-재검사로 IT-ACBC의 신뢰도를 분석한 결과, $\mathrm{r}=$ 0.962 로 $p<0.001$ 유의수준에서 매우 높은 수준의 검사-재검 사 신뢰도를 보였다.

본 연구에 참여한 대상자 중 남아 83명, 여아 93명을 대상으 로 성차 분석을 실시한 결과, 월령단계별 성차 분석을 위해 $t-$ 검정을 실시한 결과, 청각 및 의사소통 행동이 각각의 월령구간 내에서 통계적으로 유의미한 차이를 보이지 않았다 $(p<0.05)$.

\section{$\mathrm{IT}-\mathrm{ACBC}$ 의 평가 기준}

각 월령구간별 총점의 평균과 표준편차는 1 3개월은 4.9점 ( \pm 2.0$), 4 \sim 5$ 개월은 7.6점 $( \pm 2.3), 6 \sim 7$ 개월은 9.5점 $( \pm 2.2), 8 \sim 9$ 개 월은 11.5점 $( \pm 3.5), 10 \sim 11$ 개월은 14.4점 $( \pm 2.9), 12$ 13개월은 17.8점( \pm 4.9$), 14 \sim 15$ 개월은 19.6점( \pm 4.1$), 16 ~ 17$ 개월은 22.9( \pm 4.5), 18 19개월은 24.9점( \pm 5.4$), 20$ 21개월은 28.8점( \pm 4.5$)$, 22 23개월은 31.6점 $( \pm 3.3), 24 \sim 26$ 개월은 33.0점 $( \pm 3.7)$ 이었다. 총 점수가 +1 표준편차 이상일 경우 '빠른 수준' \pm 1 표준편차 이내일 경우 ‘또래 수준, -1 표준편차 미만에서 -2 표준편차 이 상인 경우 ‘추적검사 요망', -2 표준편차 미만일 경우 ‘심화 평가 권고'로 구분하기 위하여 -2 표준편차는 $\mathrm{C}$ 로, -1 표준편차는 $\mathrm{B}$ 로, +1 표준편차의 값은 $\mathrm{A}$ 로 표기하여 $\mathrm{A}$ 이상이면 '빠른수준', $\mathrm{B}$ 이상 $\mathrm{A}$ 미만은 '또래수준, $\mathrm{C}$ 이상 $\mathrm{B}$ 미만은 ‘추적검사 요망', $\mathrm{C}$ 미만은 ‘심화평가 권고’로 구분할 수 있도록 하여 IT-ACBC 도구에 결과지도 포함하였다(Table 2, Appendix 1, 2).

\section{$\mathrm{IT}-\mathrm{ACBC}$ 와 $\mathrm{K}-\mathrm{DST}$ 와의 상관관계}

청각 및 의사소통 행동을 6개의 전반적 영역과 비교하기 위 하여 총 164 명이 IT-ACBC와 함께 $\mathrm{K}-\mathrm{DST}$ 응답에 참여하였다.

Table 2. Average and standard deviation of IT-ACBC

\begin{tabular}{|c|c|c|c|c|c|}
\hline Age (months) & Mean (months) & Standard deviation & $\mathrm{A}$ & $\mathrm{B}$ & $\mathrm{C}$ \\
\hline $1-3$ & 4.9 & 2.0 & 7 & 3 & 1 \\
\hline $4-5$ & 7.6 & 2.3 & 10 & 5 & 3 \\
\hline $6-7$ & 9.5 & 2.2 & 12 & 7 & 5 \\
\hline $8-9$ & 11.5 & 3.5 & 15 & 8 & 4 \\
\hline $10-11$ & 14.4 & 2.9 & 17 & 12 & 9 \\
\hline $12-13$ & 17.8 & 4.9 & 23 & 13 & 8 \\
\hline $14-15$ & 19.6 & 4.1 & 24 & 16 & 11 \\
\hline $16-17$ & 22.9 & 4.5 & 27 & 18 & 14 \\
\hline $18-19$ & 24.9 & 5.4 & 30 & 19 & 14 \\
\hline $20-21$ & 28.8 & 4.5 & 33 & 24 & 20 \\
\hline $22-23$ & 31.6 & 3.3 & 35 & 28 & 25 \\
\hline $24-26$ & 33.0 & 3.7 & 36 & 29 & 26 \\
\hline
\end{tabular}

IT-ACBC: Infant-Toddler Auditory and Communicative Behavioral Checklist 
Table 3. Correlation between auditory and communicative behavioral ability and 6 general developmental skills with IT-ACBC and K-DST

\begin{tabular}{|c|c|c|c|c|c|c|c|}
\hline \multirow{2}{*}{ Domain } & \multirow{2}{*}{ IT-ACBC } & \multicolumn{6}{|c|}{ K-DST } \\
\hline & & Large muscle & Small muscle & Cognition & Language & Sociality & Self-help \\
\hline Auditory and communicative behavior & - & & & & & & \\
\hline Large muscle & 0.108 & - & & & & & \\
\hline Small muscle & $0.243^{*}$ & $0.262^{*}$ & - & & & & \\
\hline Cognition & $0.397^{*}$ & $0.224^{*}$ & $0.430^{*}$ & - & & & \\
\hline Language & $0.426^{*}$ & 0.148 & $0.341^{*}$ & $0.502^{*}$ & - & & \\
\hline Sociality & $0.349^{*}$ & $0.257^{*}$ & $0.352^{*}$ & $0.441^{*}$ & $0.604^{*}$ & - & \\
\hline Self-help & $0.270^{\dagger}$ & 0.244 & $0.364^{*}$ & $0.318^{\dagger}$ & 0.242 & $0.585^{*}$ & - \\
\hline
\end{tabular}

${ }^{*} p<0.01,{ }^{\dagger} p<0.05$. IT-ACBC: Infant-Toddler Auditory and Communicative Behavioral Checklist, K-DST: Korean Developmental Screening Test for Infants and Children

$\mathrm{IT}-\mathrm{ACBC}$ 를 통한 청각 및 의사소통 행동과 $\mathrm{K}-\mathrm{DST}$ 의 6개의 영 역의 상관성을 분석한 결과, 청각 및 의사소통 행동이 대근육 운동과는 유의한 상관관계를 보이지 않았으나, 언어영역과 $p<$ 0.01 수준에서 $r=0.426$ 으로 약한 유의미한 상관관계를 보였으 며, 소근육 운동, 인지, 사회성 영역과 $p<0.01$ 수준에서 유의 한 정적 상관을 나타냈고, 자조 영역과 $p<0.05$ 수준에서 유의 한 정적 상관을 나타내었다(Table 3). K-DST의 6개 영역 간에 서는 소근육 운동-인지, 인지-언어, 인지-사회성, 언어-사회성, 사회성-자조 영역이 $p<0.01$ 수준에서 상관계수가 0.4 이상으 로 약한 유의미한 상관관계를 보였다.

\section{DISCUSSIONS}

IT-ACBC는 영유아 초기의 청각 및 의사소통 행동을 짧은 시간에 월령구간별로 구조적으로 평가할 수 있는 36문항으로 구성된 부모보고형 설문지이다. 본 연구를 통해 IT-ACBC가 월령구간별로 영유아의 청각 및 의사소통 행동을 평가하는 데 적절한지 신뢰도와 타당도를 검증하고, 평가를 위한 기준을 제 시한 후 최종 IT-ACBC 검사지에 결과지로 포함하였다. 또한, $\mathrm{IT}-\mathrm{ACBC}$ 와 $\mathrm{K}-\mathrm{DST}$ 와의 상관성을 평가하여 두 검사도구의 특 성을 분석하였다.

본 연구에서 287 명을 대상으로 얻은 결과를 선행연구인 Park \& Kim(2016)의 결과와 비교할 때 신뢰도 분석에 의해 제 거되었던 문항이 양 연구 모두 동일하여 일관된 결과를 나타내 었다. 최종 36문항의 Cronbach's $\alpha$ 값은 0.964였고, 월령구간별 로 분석한 결과 1 3개월 문항은 0.457, 4 5개월 문항은 0.623 으로, 초기 문항에 제외한 월령구간에서 0.700 이상으로 높은 신뢰도를 보였다. 1 3개월 문항에서 낮은 신뢰도가 나타난 이 유는 정상 청력의 영유아이지만 월령이 증가함에 따라 초기 행 동이 잘 기억나지 않아 체크하지 않은 경우가 많았던 것으로 사 료된다. 어린 월령의 내적 일치도는 다른 연구에서도 비교적 낮 게 나타났는데, 한국어판 영유아 언어 및 의사소통 선별검사의
타당도 및 신뢰도 연구에서도 4개월부터 36개월까지 3개월 단 위로 월령구간을 나누어 Cronbach's $\alpha$ 를 확인하였을 때 0.668 0.943이었으나, 초기 월령구간인 4 6개월의 Cronbach's $\alpha$ 는 0.668로 0.700 이하의 Cronbach's $\alpha$ 를 나타내었다(Pae et al., 2015). 따라서 해당 월령 이전의 월령구간 행동을 잘 회상하 여 아주 어린 월령구간의 행동도 빠짐없이 체크하도록 안내해 야 한다고 생각한다.

70명을 대상으로 실시한 검사-재검사 결과 $r=0.962$ 로, 부모 가 아동의 청각 및 의사소통 행동을 신뢰롭게 보고할 수 있는 것으로 판단할 수 있는 높은 상관을 보였고, 듣기발달을 확인하 는 유사한 검사도구인 $\mathrm{LEAQ}-\mathrm{K}$ 를 활용하여 73명을 대상으로 실시한 공인타당도 검증 결과 상관관계가 $\mathrm{r}=0.906$ 으로 IT$\mathrm{ACBC}$ 가 영유아의 청각 능력을 평가하기에 타당한 도구임을 입증하였다. 또한, 성별 차이가 있는지 확인하기 위하여 178 명 을 대상으로 월령구간별로 $t$-검정을 실시한 결과, 청각 및 의사 소통 행동이 각각의 월령구간 내에서 남녀 간 성차를 보이지 않았다. 이는 IT-ACBC가 영유아의 청각발달을 특정한 성별에 영향을 받지 않고 월령구간별로 보편적으로 평가할 수 있는 도 구임을 입증하였고, 0 48개월을 대상으로 진행된 영유아 청각 행동발달검사 개발을 위한 기초연구(Lee \& Jang, 2010)와 0 24 개월을 대상으로 진행된 '한국어 LittlEARS Auditory Questionnaire를 이용한 건청과 청각장애 아동의 듣기 발달 연구' 에서 성별에 따른 유의미한 차이가 없었다는 결과와 일치한다 (Sohn et al., 2015).

또한, $\mathrm{IT}-\mathrm{ACBC}$ 가 $\mathrm{K}-\mathrm{DST}$ 의 6 개의 전반적 발달과 $\mathrm{r}=0.700$ 이상의 높은 상관관계가 없음을 통해 전반적인 발달평가도구 와 비교할 때 IT-ACBC의 독립성을 확인하였고, 전반적 영역에 서 청각 및 의사소통 행동 영역이 포함되지 않아 상관성이 미 비하였던 것으로 생각된다. 예를 들어, $\mathrm{K}-\mathrm{DST}$ 의 4 5개월 구간 의 언어 문항은-1) "아", "우", "이” 등 의미 없는 발성을 한다. 2) 아이를 어르거나 달래면 옹알이로 반응한다. 3) 웃을 때 소리를 내며 웃는다.-등의 문항들처럼 소리 듣기 반응보다는 발성에 
관한 언어발달에 대한 문항이 집중되어 있어, 초기 청각 및 의 사소통 행동의 독특한 발달 능력을 판단하는 IT-ACBC와 다 른 검사임을 확인할 수 있었다. 따라서 여러 발달 영역에 기반 이 되는 청각 및 의사소통 행동을 독립적으로 평가하기에 IT$\mathrm{ACBC}$ 가 적절함을 확인하였고, $\mathrm{IT}-\mathrm{ACBC}$ 가 $\mathrm{K}-\mathrm{DST}$ 를 통해 청각장애 영유아의 중재를 계획하고 진전도를 평가할 때 듣기 발달과 함께 전반적인 발달을 확인하는 데 함께 사용될 수 있 는 도구임을 확인하였다. 더욱이 두 개의 검사 도구는 월령구 간이 같으며 모두 우리나라 문화와 정서를 반영하였고, 검사 결 과 척도를 -2 표준편차로 정상 범위를 나누기 때문에 호환 가 능하여 더욱 활용도가 높을 것으로 생각된다.

현재까지 영유아 시기부터 청각행동의 발달을 선별할 수 있 는 도구가 없어 정기적인 청각학적 평가가 제대로 이루어지지 못하였지만, IT-ACBC를 통해 정상 및 청각장애 영유아의 청 각 및 의사소통 행동에 대한 선별검사를 할 수 있게 되었다. 부 모보고에 의한 선별검사이기 때문에 아주 정확한 진단은 불가 능하지만, ‘추적검사 요망’이나 '심화평가 권고'에 해당하는 경우 정밀한 객관적·주관적 청력검사를 실시하고 청각 및 의사소통 행동을 주기적으로 모니터링하여 청각장애의 적절한 조기 중 재, 관리, 평가가 이루어질 수 있을 것으로 생각된다 또한, IT$\mathrm{ACBC}$ 와 $\mathrm{K}-\mathrm{DST}$ 를 함께 사용하여 청각 및 의사소통 행동 발 달과 전반적 발달을 함께 확인할 경우 청각장애 부모와 보청기 착용이나 인공와우 수술 결정을 하는 상담에 있어서 전반적 영 역에 문제가 있음을 조기에 간단하게 판단할 수 있는 점도 임 상에서 사용할 수 있는 장점으로 생각된다. 따라서 IT-ACBC는 빠르고 쉽게 청각 및 의사소통 행동에 대한 정보를 제공하여 청각장애의 조기 진단과 조기 재활에 활용할 수 있고, $\mathrm{K}-\mathrm{DST}$ 와 연계하여 영유아의 전반적인 건강관리를 더욱 체계적으로 평가하고 향상시키는 도구로 사용할 수 있다.

중심 단어 : 영유아-청각 및 의사소통 행동 발달. 영유아 발달. 체크리스트·선별검사.

\section{Acknowledgments}

본 연구는 2015년 대한민국 교육부와 한국연구재단의 중견연구자 지원사업(인문사회: H00159) 지원을 받아 수행된 연구임(NRF2015S1A5A2A01011541).

\section{REFERENCES}

Abrams, R. M. \& Gerhardt, K. J. (2000). The acoustic environment and physiological responses of the fetus. Journal of Perinatology, 20(8 Pt 2), S31-S36.

Chang, H. S., Seo, S. J., \& Ha, J. Y. (2011). Developmental Assessment for the Early Intervention Program Planning (DEP). Seoul: Hakjisa.

Coninx, F., Weichbold, V., \& Tsiakpini, L. (2003). LittlEARS Auditory Questionnaire. Innsbruck: MED-EL.

Eun, B. L. \& Jeong, H. J. (2013). A Study on the Development and Validation of Korean Developmental Screening Test for Infants and Children. Cheongju:
Korea Centers for Disease Control and Prevention.

Eun, B. L. \& Jeong, H. J. (2014). Korean Developmental Screening Test for Infants and Children (K-DST) Manual. Korea Centers for Disease Control and Prevention. Retrieved from http://cdc.go.kr/CDC/notice/CdcKr Together0302.jsp?menuIds=HOME001-MNU1154-MNU0005-MNU $0088 \&$ cid $=29219$.

Eun, B. L. (2012). A study on the development and validation of Korean developmental screening test for infant and children. Retrieved from http://cdc.go.kr/CDC/notice/CdcKrInfo0201.jsp?menuIds=HOME001MNU1154-MNU0005-MNU1889\&cid=21524.

Hall, J. W. 3rd. (2000). Development of the ear and hearing. Journal of Perinatology: Official Journal of the California Perinatal Association, 20(8 Pt 2), S12-S20.

Hans, P. S., England, R., Prowse, S., Young, E., \& Sheehan, P. Z. (2010). UK and Ireland experience of cochlear implants in children with Down syndrome. International Journal of Pediatric Otorhinolaryngology, 74(3), 260-264.

Ju, H. O., Lee, N. Y., Park, I. S., Lee, S. O., \& Kim, S. H. (2009). Development \& validation of a checklist for infant and child developmental screening. Journal of Korean Academy of Child Health Nursing, 15(1), 34-41.

Kim, L. S. (2007). Newborn hearing screening. Korean Journal of Pediatrics, 50(1), 7-13.

Korean Otological Society \& The Korean Audiological Society. (2011). Korean Clinical Practice Guideline: Newborn Hearing Screening 2010. Seoul: ML communication.

Lecanuet, J. P., Gautheron, B., Locatelli, A., Schaal, B., Jacquet, A. Y., \& Busnel, M. C. (1998). What sounds reach fetuses: Biological and nonbiological modeling of the transmission of pure tones. Developmental Psychobiology, 33(3), 203-219.

Lee, M. S. \& Jang, H. S. (2010). A preliminary study on the development of auditory behavior checklist for infant-toddler. Audiology, 6(1), 60-75.

Lee, Y. (2011). The relationships among language, communicative abilities and motor, cognitive, and socio-emotional development in toddlers with language delays. Communication Sciences and Disorders, 16(1), 1-12.

Meinzen-Derr, J., Wiley, S., Grether, S., \& Choo, D. I. (2010). Language performance in children with cochlear implants and additional disabilities. The Laryngoscope, 120(2), 405-413.

National Institute on Deafness and Other Communication Disorders. (2010). Your Baby's Hearing and Communicative Development Checklist. Retrieved from https://www.nidcd.nih.gov/health/your-babys-hearingand-communicative-development-checklist.

Pae, S., Yoon, H., Seol, A., \& Gilkerson, J. (2015). The validity and reliability of the Korean version of the developmental snapshot. Communication Sciences and Disorders, 20(3), 355-363.

Park, K. \& Kim, J. (2016). A developmental study for infant-toddler auditory \& communicative behavioral checklist. Audiology and Speech Research, 12(2), 65-73.

Pujol, R. \& Lavigne-Rebillard, M. (1992). Development of neurosensory structures in the human cochlea. Acta Oto-laryngologica, 112(2), 259264.

Sohn, M., Kim, J., \& Park, H. (2015). Auditory development assessment with LittlEARS ${ }^{\oplus}$ auditory questionnaire in children with and without hearing loss. Audiology, 11(1), 45-62.

Shoup, A. G. \& Roeser R. J. (2007). Audiologic evaluation of special populations. In R. J. Roeser, M. Valente, \& H. Hosford-Dunn (2nd ed.). Audiology Diagnosis (pp. 314-334). New York : Thieme.

Tait, M. E., Nikolopoulos, T. P., \& Lutman, M. E. (2007). Age at implantation and development of vocal and auditory preverbal skills in implanted deaf children. International Journal of Pediatric Otorhinolaryngology, 71(4), 603-610.

The Hearing Foundation of Canada. (2016). Baby's Communication Checklist. Retrieved from http://www.hearingfoundation.ca/babys-communication- checklist/.

Yee, Y. H. \& Oh, M. Y. (2006). A comparative study between fathers and mothers on the parenting efficacy, knowledge of infant-care and sensitivity. Korean Journal of Human Ecology, 9(3), 47-62. 


\section{APPENDICES}

\section{Appendix 1. 영유아 청각 · 의사소통 행동 체크리스트}

\section{Infant-Toddler Auditory \& Communicative Behavioral Checklist (IT-ACBC)}

\begin{tabular}{|c|c|c|c|c|c|}
\hline 이 & & 름 & & & \\
\hline 성 & & 별 & $\mathrm{O}$ 남 자 & $\circ$ 여 & 자 \\
\hline 보 & 고 & 자 & & & (부 / 모) \\
\hline 선 & $j_{3}$ | & & $\bigcirc$ 통과 & 대검권 & 고 $\bigcirc$ 난청확인 \\
\hline
\end{tabular}

\begin{tabular}{lllll}
\hline 검 사 일 & 년 & 월 & 일 \\
\hline 생 년 월 일 & 년 & 월 & 일 \\
\hline 연 락 처 & & - & & - \\
\hline
\end{tabular}

- 아기가 하는 행동에 '○'로 표기해 주세요. 아기가 아주 어렸을 때 했던 행동들도 회상하여 '○’로 표기해 주세요. 아기의 해당 월령구간에 따른 표준점수와 확인하기 위하여 이전 월령구간의 행동도 체크하여야 하니 이해하여 주시기 바랍니다.

\begin{tabular}{|c|c|c|c|c|c|}
\hline $\begin{array}{l}\text { 월령 } \\
\text { 구간 }\end{array}$ & 확인 & 청각 - 의사소통 행동 & $\begin{array}{l}\text { 월령 } \\
\text { 구간 }\end{array}$ & 확인 & 청각 · 의사소통 행동 \\
\hline \multirow{3}{*}{$1-3$} & & 갑작스런 큰 소리에 놀라거나 깬다. & \multirow{3}{*}{$14-15$} & & $\begin{array}{l}\text { 책 속의 그림을 가리키는 말(‘멍멍'-강아지, ‘빵 } \\
\text { 빵'-차, ‘음메’-소 등)을 하면 해당 그림을 가리 } \\
\text { 킬 수 있다. }\end{array}$ \\
\hline & & 큰 소리에 젓이나 우유병을 빠는 동작을 멈춘다. & & & $\begin{array}{l}\text { ‘엄마', ‘아빠' 이외에 두세 개 정도의 단어를 알 } \\
\text { 고 사용한다. }\end{array}$ \\
\hline & & $\begin{array}{l}\text { 엄마 목소리(친숙한 목소리)를 듣고 울다가 조 } \\
\text { 용해지는 등의 반응을 한다. }\end{array}$ & & & $\begin{array}{l}\text { 간단한 질문을 이해하고 한 단어(“응”, "아니” } \\
\text { 등)나 몸동작으로 답한다. }\end{array}$ \\
\hline \multirow{3}{*}{$4-5$} & & $\begin{array}{l}\text { 소리가 나는 곳을 찾으려는 행동(고개를 돌리는 } \\
\text { 등)을 한다. }\end{array}$ & \multirow{3}{*}{$16-17$} & & $\begin{array}{l}\text { 간단한 심부름(기저귀, 신발, 컵 등을 가져오기) } \\
\text { 을 한다. }\end{array}$ \\
\hline & & $\begin{array}{l}\text { 이상한 소리(자음이나 모음으로 표현할 수 없 } \\
\text { 는)를 내며 놀기 시작한다. }\end{array}$ & & & 10 20개의 단어를 알고 말한다. \\
\hline & & $\begin{array}{l}\text { 반복적인 모음 소리(/아 /, /오 /)를 내기 시작 } \\
\text { 한다. }\end{array}$ & & & 매일 새로운 단어를 배우고 사용한다. \\
\hline \multirow{3}{*}{$6-7$} & & 자기 이름에 반응하기 시작한다. & \multirow{3}{*}{$18-19$} & & 20 개 이상의 단어를 알고 사용한다. \\
\hline & & $\begin{array}{l}\text { 다양한 소리(“껄껄”, “끼끼”, “걸걸”, 비명소리, } \\
\text { ‘흐-읍’하며 들이마시는 소리 등)를 낼 수 있다. }\end{array}$ & & & $\begin{array}{l}\text { ‘나', ‘이거', ‘저거'와 같은 대명사를 사용할 줄 } \\
\text { 안다. }\end{array}$ \\
\hline & & 음악소리를 좋아하고, 반응하기 시작한다. & & & $\begin{array}{l}\text { "배고파", “쉬 마려워?”와 같은 단순한 예, 아니 } \\
\text { 오 식의 질문을 이해한다. }\end{array}$ \\
\hline \multirow{3}{*}{$8-9$} & & 자기 이름에 작은 소리로 불러도 확실히 반응한다. & \multirow{3}{*}{$20-21$} & & “이게 뭐야”와 같은 간단한 질문에 답한다. \\
\hline & & ‘까꿍’이나 ‘짝짜꿍' 놀이 등을 따라하고 즐긴다. & & & 말로 하는 간단한 지시 사항에 따라 행동한다. \\
\hline & & $\begin{array}{l}\text { 익숙한 물건의 이름(혹은 단어; 컵, 신발, 우유, } \\
\text { 까까 등)을 안다. }\end{array}$ & & & 집에서 사용하는 다양한 일상적 어휘를 사용한다. \\
\hline \multirow{3}{*}{$10-11$} & & $\begin{array}{l}\text { 말소리와 같은 옹알이로 의사 표현을 하고 대화 } \\
\text { 하듯 응답할 수 있다. }\end{array}$ & \multirow{3}{*}{$22-23$} & & 단어의 끝 억양을 높여 질문의 형태로 묻는다. \\
\hline & & 간단한 말소리를 따라 내거나 흉내 낼 수 있다. & & & $\begin{array}{l}\text { 세 단어 이상을 사용하여 문장을 말한다(“아가 } \\
\text { 코 자", "나 우유 시러” 등) }\end{array}$ \\
\hline & & $\begin{array}{l}\text { 지시어(“가져와”, "이리 와”, “더 줄까?” 등)의 의 } \\
\text { 미를 알고 행동한다. }\end{array}$ & & & $\begin{array}{l}\text { “컵 안에”, “책상 밑에”, “의자 위에” 등의 부사 } \\
\text { 구를 이해한다. }\end{array}$ \\
\hline \multirow{3}{*}{$12-13$} & & $\begin{array}{l}\text { 어른들이 사용하는 어구(“이거 지지”, "아빠, 빠 } \\
\text { 이빠이” 등)의 억양을 흉내 낼 수 있다. }\end{array}$ & \multirow{3}{*}{$24-26$} & & 사물의 크기를 구분한다(큰/작은 공). \\
\hline & & $\begin{array}{l}\text { 지시어(“가져와”, “이리 와”, “더 줄까?” 등)뿐만 } \\
\text { 아니라, “너 신발 어디 있어?”와 같은 간단한 질 } \\
\text { 문도 이해한다. }\end{array}$ & & & 배설 욕구를 말이나 행동으로 표현한다. \\
\hline & & $\begin{array}{l}\text { ‘엄마’, ‘아빠’ 이외에 적어도 한 단어 이상을 알 } \\
\text { 고 사용한다. }\end{array}$ & & & "어디?"나 "언제?"와 같은 질문에 답한다. \\
\hline
\end{tabular}


Appendix 2. 영유아 청각 - 의사소통 행동 체크리스트 결과지

Infant-Toddler Auditory \& Communicative Behavioral Checklist (IT-ACBC)

\begin{tabular}{|c|c|c|c|c|c|c|c|}
\hline 이 & & 름 & & 검 사 일 & 년 & 월 & 일 \\
\hline 성 & & 별 $\bigcirc$ 남 자 & ○여 자 & 생 년 월 일 & 년 & 월 & 일 \\
\hline 보 & 고 & 자 & (부 / 모) & 연 락 처 & & & \\
\hline
\end{tabular}

- 아이의 해당 월령구간 옆 총점란에 36문항 중 ' $\bigcirc$ '로 응답한 총 수를 기입해 주세요.

\begin{tabular}{|c|c|c|c|c|}
\hline 월령구간 & 총점 & A & $B$ & $C$ \\
\hline $1-3$ & & 7 & 3 & 1 \\
\hline $4-5$ & & 10 & 5 & 3 \\
\hline $6-7$ & & 12 & 7 & 5 \\
\hline $8-9$ & & 15 & 8 & 4 \\
\hline $10-11$ & & 17 & 12 & 9 \\
\hline $12-13$ & & 23 & 13 & 8 \\
\hline $14-15$ & & 24 & 16 & 11 \\
\hline $16-17$ & & 27 & 18 & 14 \\
\hline $18-19$ & & 30 & 19 & 14 \\
\hline $20-21$ & & 33 & 24 & 20 \\
\hline $22-23$ & & 35 & 28 & 25 \\
\hline $24-26$ & & 36 & 29 & 26 \\
\hline
\end{tabular}

- 총점에 대한 평가는 해당 월령의 $\mathrm{A}, \mathrm{B}, \mathrm{C}$ 절단점에 근거하여 다음과 같이 평가합니다.
(1) 총점이 'A' 이상
: 빠른 수준
(2) 총점이 'B' 이상 'A' 미만
: 또래 수준
(3) 총점이 ' $\mathrm{C}$ ' 이상 ' $\mathrm{B}$ ' 미만
: 추적검사 요망
(4) 총점이 ' $C$ ' 미만
: 심화평가 권고 